UDC 005.7:622.012(4+73)

\title{
SAPYTSKA IRYNA,
}

Candidate of Science (Engineering), Assistant Professor, Vasyl Stus Donetsk National University, Vinnytsia, Ukraine

CHUDEK MIROSLAW,

Prof. zw. hab. inz.,

Silesian University of Technology, Gliwice, Polska

MALTSEVA IRYNA,

Candidate of Science in Public Administration, Associate Professor,

Vasyl Stus Donetsk National University, Vinnytsia, Ukraine

\section{ORGANIZATIONAL CHANGES IN THE COAL INDUSTRY FOREIGN COUNTRIES}

In the article is determined that the coal industry in many foreign countries was carried out reform, which results in the search for effective ways of taking organizational, financial, socioeconomic and technical solutions.

Briefly considered the experience of organizational changes in the coal industry countries such as Poland, Germany, France, UK, Belgium, Spain, USA. The basic goal of this process. Substantiates the role of the state, stages and methods of restructuring of the coal mines. To characterize the socio-economic aspects of changes in different countries.

Keywords: organizational changes; coal industry; foreign experience; socio-economic support.

Formulation of the problem. State energy sector directly affects the economic situation of the state, the solution of social sphere problems, ensuring the energy security of the country. Energy security is closely linked to the national. An important component of energy security is to develop its own coal-mining and energy sectors.

Trends in the development of world energy show that in the coming decades the role of coal in the energy sector will increase. Data on coal reserves and marks shown in Fig. 1 and Tab. 1 confirm the possible predictions of scientists [11].

In order to get the available coal reserves, and then to implement them, need a stable work of the coal enterprises. However, in a sharp rise in the cost of extraction and processing of coal, resource depletion in some parts of the world, mines operate erratically. In order to stabilize their work carried out scientific studies that proved the need for organizational change.

Analysis of recent research and publications. Great contribution to the scientific development of these scientists has made: R. Ackoff [1], I. Ansoff [3], B. Milner [6], J. Mazur, B. Shapiro [7], etc. The theoretical foundations of the process of organizational changes designed yet in the 60 s XX cent. I. Ansoff and R. Ackoff They offered their usage patterns in various firms. B. Milner, J. Mazur and B. Shapiro discusses the practical and theoretical aspects, in particular, the procedures for the implementation of changes, a situational analysis of modern enterprises, structural shapes, etc. But immediately the problems of organizational changes are considered weak for the coal industry.

The purpose of this article is to study the practical experience and the characteristics of the organizational

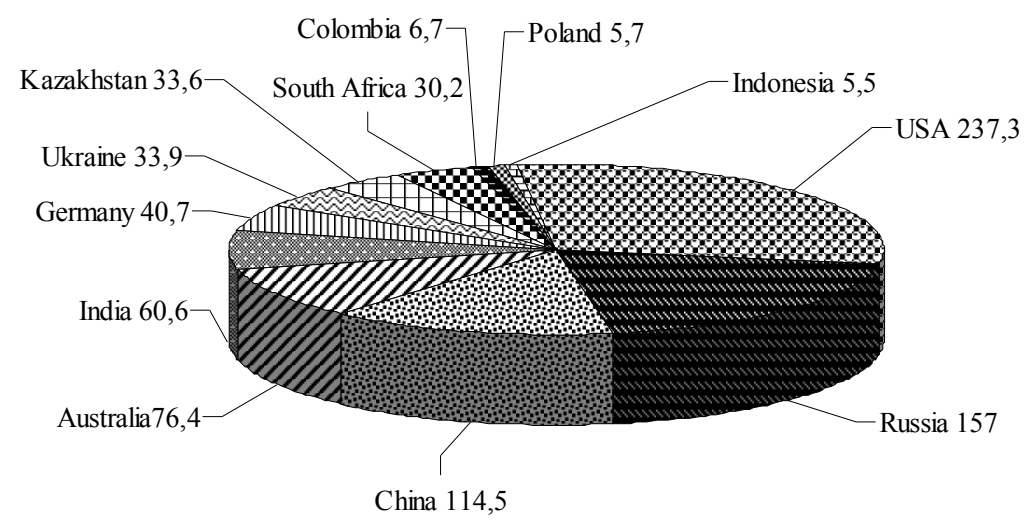

Figure 1. Coal country, billion tons. 
Table 1. Reserves, production and consumption of coal worldwide

\begin{tabular}{|c|c|c|c|c|c|c|c|}
\hline Country & $\begin{array}{c}\text { Anthracite and } \\
\text { bituminous } \\
\text { coal, } \\
\text { billion tons }\end{array}$ & $\begin{array}{c}\text { Sub-bituminous } \\
\text { coal and lignite } \\
\text { billion tons }\end{array}$ & $\begin{array}{l}\text { Coal } \\
\text { reserves, } \\
\text { billion tons }\end{array}$ & $\begin{array}{c}\text { Coal } \\
\text { mining, } \\
\text { million tons. } \\
\text { AD / year }\end{array}$ & $\begin{array}{l}\text { Multi } \\
\text { plicity of } \\
\text { stocks, } \\
\text { years }\end{array}$ & $\begin{array}{c}\text { Coal } \\
\text { consumption, } \\
\text { million tons. } \\
\text { AD / year }\end{array}$ & $\begin{array}{l}\text { Export / } \\
\text { import of } \\
\text { coal, million } \\
\text { tons. AD }\end{array}$ \\
\hline USA & 108,5 & 128,8 & 237,3 & 516 & 257 & 438 & 77,9 \\
\hline Russia & 49,0 & 107,9 & 157,0 & 168 & 443 & 94 & 74,0 \\
\hline China & 62,2 & 52,3 & 114,5 & 1825 & 31 & 1873 & $-48,0$ \\
\hline Australia & 37,1 & 39,3 & 76,4 & 241 & 177 & 49 & 192,0 \\
\hline India & 56,1 & 4,5 & 60,6 & 229 & 100 & 298 & $-69,0$ \\
\hline Germany & 0,0 & 40,6 & 40,7 & 46 & 207 & 79 & $-33,0$ \\
\hline Ukraine & 15,4 & 18,5 & 33,9 & 46 & 364 & 45 & 1,0 \\
\hline Kazakhstan & 21,5 & 12,1 & 33,6 & 59 & 289 & 35 & 24,0 \\
\hline South Africa & 30,2 & 0,0 & 30,2 & 146 & 116 & 90 & 56,0 \\
\hline Colombia & 6,4 & 0,3 & 6,7 & 58 & 76 & 4 & 54,0 \\
\hline Poland & 4,3 & 1,4 & 5,7 & 59 & 40 & 54 & 5,0 \\
\hline Indonesia & 1,5 & 4,0 & 5,5 & 237 & 14 & 50 & 187,0 \\
\hline
\end{tabular}

changes in the coal industry of European countries and the United States to adapt to the conditions of Ukraine.

Based on the goal, the following objectives were identified:

- describe the process of organizational changes in the coal industry in Poland, Germany, France, UK, Belgium, Spain and the United States;

- identify the specific development objectives and main directions of the state policy of the coal industry of foreign countries;

- disclose activities on social protection of redundant mine workers in European countries and the United States.

The object of research is the coal industry in some European countries and the United States.

Statement of the base material. Ukraine has passed a long-term path of reforming the coal industry. Unfortunately, this was mainly used, the method of "trial and error" due to lack of government strategy for economic and social development, energy development concepts; insufficiently substantiated, organizational activities in solving of complex problems, a change in objectives.

For Ukraine, it is expedient to analyze and learn from foreign experience in the field of organizational changes relating to the coal industry, forms of social protection of miners, legislative support of reforming the industry, forms and sizes of state support. In this regard, an example of role model for Ukraine could be Poland, Germany, Britain, France, the United States and some other countries. The results of the research in Fig. 2 present the main objectives of organizational change in the coal-mining industry in foreign countries.

In most countries, the coal industry, which determines the energy security, is under special control and protection of the State. It, along with social programs in the reform of Mines holds a protectionist policy with regard to coal imports supports businesses by providing incentives, subsidies and targeted subsidies for the technical and technological renewal of production and invests in science and technology and environmental programs. Economic support is provided to consumers and businesses, domestic coal - particularly stimulated by improving the efficiency of combustion, the replacement of oil, with the state's actions are long-term.

The increase in coal production volumes targeted the United States, India, China. In these countries there are huge deposits of coal. And its production is relatively cheap and does not require high production costs.

The opposite direction of the development of the coal industry has chosen Germany, UK, Belgium and France. Reduction of volumes of coal caused by the depletion of

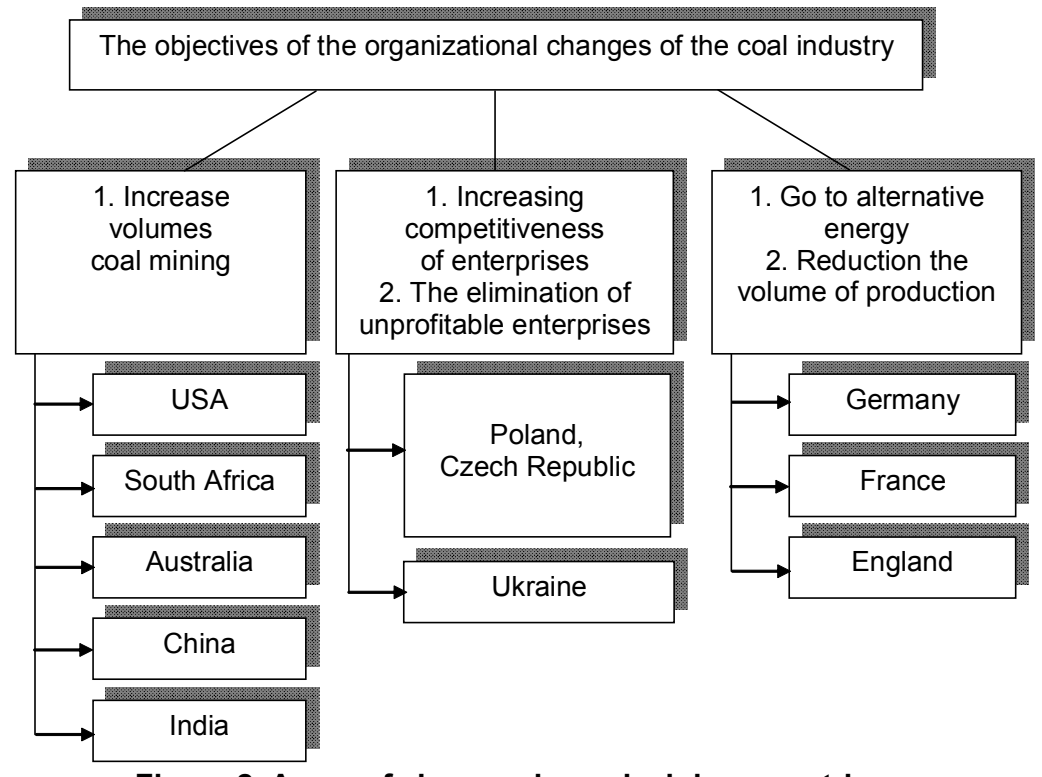

Figure 2. Areas of changes in coal mining countries. 
coal reserves and use of other fuels and energy sources: solar, wind, tidal, nuclear energy.

For Ukraine and Eastern European countries are characterized by complex and dangerous geological conditions, where coal mining requires excessive costs. Therefore, the main purpose of the changes in these countries is the closure of unprofitable mines, improving the competitiveness of coal production.

Through organizational changes in the coal industry, each country uses its industrial policy options.

Annual coal production in Poland in the late 80 s XX century was about 200 million tons; about 450 thousand people were employed in the industry. Since 1989 , due to changes in the social order began deregulation of the economy, liberalization of prices, which also affected the coal industry. Real reform in the industry began in 1995. As part of the coal companies were allocated the mines, which were planned organizational changes, create a structure for the sale of the property, use it for other activities not related to coal, organized private firms for coal mining support services [4]

In the late 90 s of XX century, the industry produced more than 132 million tons of coal and about 243 thousand of people were employed. Without a major social conflict 172 thousand men was released, completely eliminated 15 unprofitable mines and 11 partially closed or merged with the other, stopped 60 barrels from 360 . It is also Government's program of reforming the industry has been developed [10]

Parliament adopted a law on the regulation of the coal industry in a market economy and of special rights miner governments. The Law determines the sources of financing, the special rights of mining regions, regulated the procedure of liquidation of mines, industry management structure, and discussed the problem of employment. Together with the trade unions was adopted "Mining social package" that defines the rights of redundant miners, the order of severance payments and unemployment, credit for the creation of small businesses, free training to new specialties. The "Mining Labour Agency" was organized by the city of Katowice with 38 offices in the miner districts. In the city of Gliwice created "Silesian Fund for Entrepreneurship Support" and "Local Development Agency" [10].

For Ukraine, which has close to Poland capabilities are of special interest social security principles. Miner, who before retirement remains no more than 5 years, is offered on a voluntary basis, to take a five-year leave of absence, during which they will receive $75 \%$ of the monthly remuneration of the holiday; if the remains of 3 years, - a mandatory three-year vacation. Miners liquidated enterprises, which until retirement 2 years, have the right to move to other operating mines. Those who before retirement are still more than five years, offered the following options of social protection. If you change the place of work - one-time retraining courses and $65 \%$ of the former salary, the allowance for two years or a lump sum of about 10 thousand dollars without the right to work in the future in the industry and to apply for a variety of social benefits. Under the guarantee of the government provided loans with low interest rates and the possibility of write off. Provision economic incentives for employers [5].

In Germany, the Ruhr mining pool, which is close to Donbas on geological conditions (considerable depth of development, the presence of steep seams), as well as on the problems that arose in Germany $30-40$ years ago. Approaches and the positive results of the reform of the sector are largely paradigmatic character. In 1957 in Germany it operated 173 mines were produced 149 million tons of coal, of which 30 million tons were exported. Since then, the production decline was due to the lack of competitiveness of the German coal, there is a problem of uncontrolled mine closures, job losses and increased unemployment [2].

The government has been consistently reforming the industry. In 1968 it adopted the "Law on the companies to adapt to market conditions and the recovery of the coal industry in Germany and its coalfields." The law systematically identified measures harmonizing production volumes and coal sales, stimulate the concentration of enterprises of coal industry, tax and other incentives, took into account the peculiarities of regions and interests of the state, federal and state financial guarantees, conditions of nationalization (ransom) of enterprises, monetary compensation for dismissed employees, controls and responsibility.

In 1969, between the German government and the 26 existing coal companies signed an agreement in the form of the Treaty establishing the Group (joint stock company) "Rurkole AG". The objectives of the agreement: adaptation of coal production volumes to the changed conditions; the operation of coal mines with maximum efficiency; centralized policy regarding labor groups, prevent mass unemployment; carrying out measures to improve the structure of the industry. The agreement includes issues of property, economic, legal, regional and socio-political character [10]

Over 20 years of dedicated work in Germany was able to solve the problem: the number of mines has decreased to 19 with an annual output of 58 million tons, the average daily load of mines, using the most modern technology and equipment, increased from 3.3 to 12.5 thousand tons. Of interest is the process of closing the mines. In 1968, coal companies have received 2.9 billion stamps at the closing of old mines imperative to invest in agriculture and coal regions for four years to create new jobs [8].

The state began to pursue a policy of engaging in coal regions in the automotive industry, the non-productive sphere, and later the electrical and electronics industry. The federal government has set up "investment premium" for the improvement of the economic structure of the regions. Given the nature of the subsidy, the coal industry did not pay the basic tax on profits, and VAT has been reduced. It was introduced a tax on electricity consumers, the so-called "carbon pfennig" for the payment of subsidies. At the same time $70 \%$ of the subsidies allocated by the federal government, $30 \%$ - from the land fund. At the same time held the most severe administrative and financial control. Concern "Rurkole" responsible, including criminal, the federal and state governments for the disbursement of the allocated funds as grants.

Design and construction of new mines until 1989 carried out at the expense of the state, then - at the expense of the group within the accrued depreciation. Concern "Rurkole AG", created by large enterprises and the steel industry, electric power, has become a multi-trade industrial and fuel and energy complex for the extraction, coal processing and sales.

Concern receives as a result of diversification and organizational changes more than $40 \%$ profit on turnover, not associated with the coal industry. Thus, included in it mountain-industrial associations together with energy became engaged in the production of building materials, housing construction and maintenance of buildings, design, construction and operation of brick plants, leasing of construction machinery and industrial plants, environmental protection, recycling, sanitation of old enterprises, land reclamation, development of new technologies [10].

Diversification touched and mining science, which is 
in parallel with the objectives of the coal industry solved and solves the problems of the construction of the tunnel under the English Channel to save the Leaning Tower of Pisa, underwater concreting issues, strengthening polyurethane and silicate resins rocks in the construction and other. The German company has successfully exported technologies and equipment in many countries, including Ukraine. Energy Germany, for reasons of national security, is based on maintaining coal production at a certain level and the state support of the coal industry; diversification of energy supply, including the use of alternative sources (wind power, biogas, etc.).

The process of organizational change in the country took place on "soft" scenario because they were guaranteed contracts for the supply of coal to power plants and steel mills; reinforced by heavily subsidized early retirement and a massive shift of miners to other mines.

German model of "social peace and partnership," dialogue and coordination between all levels of government and representatives of local communities, trade unions is the most successful example of organizational change. Among her achievements: implementation of environmental projects (land reclamation, recycling of waste), the establishment of universities, industrial parks and technology centers with new jobs.

The coal industry has experienced UK nationalization in 1947 and privatized in 1995. Over the years, coal mining has decreased several times, the number of mines - from 211 to 20 , the number of employees - from 500 thousand to 15 thousand people. The privatization of the coal industry took place fairly quickly. In 1992, the government has put forward proposals for its return to the private sector, and by the end of 1994, all five of the proposed sale package passed into the hands of new owners. At the same time the industry has achieved high productivity and is currently producing coal with the lowest costs in Europe [2].

Provided significant support through guaranteed sales of mined coal power plants in the state of the country on the basis of long-term agreements concluded with the support of the government; direct subsidies to cover losses; severance payments to dismissed miners, as well as the use of economic incentives dismissal of their own volition. At the same time gradually increasing the size of severance payments and reduced the age limit for entitlement to voluntary departure. Miners were offered benefits, roughly equal to the annual earnings. Alternatively they are able to move to the other mine. Force reduces staff offered an indemnity equal to double the salary and pension on reaching 50 years of age.

In order to provide alternative employment opportunities in regions where coal mines were closed, in 1985 it was created a specialized company "British Coal Enterprise", which has been working in the following areas:

- the allocation of loans on favorable terms for the needs of new and existing companies, where new jobs are created;

- rental companies (usually in the field of electricity, heating, telephone, etc.) For new small businesses;

- provision of employment services:

- partial funding for local non-profit organizations promoting the development of small businesses.

As a result, it managed to create 90 thousand jobs, which corresponds to $70 \%$ of staff cuts, including retirement. At the same time "British Coal Enterprise" incurred costs per seat below the average monthly earnings miner. New mine owners had paid the state about 1.5 billion dollars, which are largely spent on the elimination of the negative social consequences of privatization. In some cases, miners took a real part in the privatization of enterprises.
In order to increase coal production in the conditions of post-war economic recovery French government nationalized the coal industry, creating a state company "Charbonnages de France" (CdF). In the early 60s of XX century was adopted energy strategy, which provides intensive development of nuclear power and the gradual closure of mines. State support is to ensure the sales of the state company "Electric de France" of coal, direct production subsidies and social issues. Every year for the purpose allocated about 1 billion dollars.

Priority has been given no early retirement, and retraining and employment of miners. Specially designed programs implemented beginning two years before the closure of a particular mine, the cost of one person matched his earnings in two years. Public funding of the organization of new jobs in mining regions was carried out through a special company SOFIREM, that when the volume of financing of about 50 million dollars. It created a year annually to 6 thousand jobs.

It was changed Mining Code, in the 90 s of the XX century, which pay more attention to environmental protection. Conducted changes in training engineering personnel. Training and research have been redirected to the construction of underground structures for various purposes, for waste processing and oil production.

Belgian government's decision to reduce, and then to abandon coal production in the country was caused mainly increasing public pressure aimed at stopping industry subsidies.

The Government has developed the program "Future Contract", which included not only the closure of the mines, but also upgrades the economic activity of the region. It was planned to increase the level of employment and education to the national average, as well as the conversion of industrial sites and waste storage sites in the commercial and educational centers, rest areas.

In 1987, the company owner "Kempische Steenkoolmijnen NV" mines were nationalized, and the closure of the mines was carried out ahead of schedule (1996). However, updating the economic activity of the region was quite difficult. The development of 2.2 billion dollars allocated for this purpose, it was not efficient enough, since it dealt with the local business elite. The restructuring process, save additional investments in the amount of 550 million pounds from various European funds. The company "Permanente Werkgroep Limburg", created to administer the new investment program, including representatives of all stakeholders, including trade unions. This allowed for five years to create 24 thousand jobs [10].

The process of restructuring of the coal industry in Belgium was held on "mild" scenario, due to the cooperation of all stakeholders and supported by considerable investments to relieve social tension.

The Government of Spain, in spite of pressure from the EU aimed at the closure of mines in the shortest possible time, provides a gradual reduction in industrial activity in the coal industry. The process is accompanied by a large-scale state subsidies HUNOSA company using early retirement formulas and provides a high level of social protection of miners.

Organizational changes were made on the basis of the "Plan of coal mining and the alternative development of mining regions", signed by the Government and trade unions, as well as the calculated performance for seven years. According to the plan, coal production declined from 18 million tons in 1997 to 13 million tons in 2005; subsidy - on 20-25\%; number of people employed in the industry 25000 to 1,800 [2].

Formed several agencies that are engaged in the 
creation of new jobs and retraining of miners. Restructuring generally occurred at a relatively "mild" scenario, due to the small number of miners and the substantial funding of the social sphere.

In the US up to $80 \%$ of extracted coal is consumed by electric power, with and in the future it will be cost-effective fuel for power plants.

Given the high mobility of American workers, coal companies are not special for their employment and social protection programs. The role of government is limited to the payment of ordinary unemployment benefits. Standard services on retraining and employment provide local authorities.

Direct public support to enterprises does not exist, funded only industry-wide research programs. Indirect support through strict regulation of activities of energy companies, the prohibition of the construction of power plants using gas and fuel oil. Legally regulated environmental management and safety OSH management and safety in the US mining enterprises (MSNA) performs centralized control of security.

Interests of the coal industry in the relationship with the federal government are the National Coal Association (NCA), which unites colliery owners, and the American Mining Congress (AMG) - an association whose members are the mining companies of the manufacturer of equipment, financial and other institutions serving the coal industry. The Association conducts systematic work on major activities of the mining industry and it is development.

\section{Conclusions}

The following conclusions can be drawn on the results of the research:

- organizational changes in the coal industry is characterized by virtually all countries of the world coal. Differences in the implementation process are objective, procedure implementation of public policy with respect to the coal industry, the time of their conduct. But in all powers, this process is based on each country developed the state program of reforming the coal industry. In some countries (UK, France, etc.) created companies implementing a state program. Financing of the activities carried out from the state and local budgets, intergovernmental organizations (EU, the European Coal and Steel Community, the European Association of mining regions);

- the reform process is a long and costly. Closure of loss-making enterprises of coal production entails the mass release of workers. Implementation of measures on social protection of the unemployed population is impossible without substantial financial and legal support from the government. To meet the social needs of the redundant workers was conducted diversification of coal- mining areas to attract investment for the development of new highly efficient production;

- foreign experience of coal industry restructuring should be used in the process of organizational change basic industry of Ukraine in view of the prevailing socioeconomic conditions.

\section{REFERENCES}

1. Ackoff, R. (1982), The art of problem-solving, Mir, Moscow, 224 p. (rus)

2. Alymov, V.A., Garbuzenko, L.N. and Bogatyrenko, N.N. (2006), Generalization of the experience of foreign countries on the restructuring of the coal industry, IEP of the NAS of Ukraine, Donetsk, 24 p. (rus).

3. Ansoff, I. (1989), Strategic Management [translat.], Economics, Moscow, 382 p. (rus).

4. Biletsky, V., Kozlovsky, A. (2008), Coal Industry of Ukraine and Poland: current situation and prospects, Skhid (ISSN 17289343), No.7, pp. 3-10 (ukr).

5. Karbovnik, A. and Tursin, M. (2007), The course of the restructuring of the coal industry in Poland from 1998-2006, Gluckauf, No. 4, pp. 52-57 (rus).

6. Milner, B.Z. (1999), Theory of Organizations, Infra-M, Moscow, 333 p. (rus).

7. Mazur, I. I. and Shapiro, V.D. (2000), Restructuring of enterprises and companies, Vyshaya Shkola, Moscow, 587 p. (rus).

8. Sapitskaya, I.K. (2001), Foreign Experience in Management of Mining Industries, Ugol Ukrainy, No. 2-3, pp. 68-70.

9. Sapytska, I.K. (2011), Corporate structures as the basis for the development of coal enterprises, Skhid (ISSN 1728-9343), No. 4, pp. 64-67 (ukr).

10. Chudek, M. and Sapicki, K.F. (2004), Environmental Protection in Upper Silesia and the Donetsk coal basin, Silesian University of Technology, Gliwice, 592 p. (pol).

11. Reserves, coal production and consumption in the main coal-mining countries, available at: http://ray-idaho.livejournal.com/ 291572.html

12. Biletsky, V. [Ed.] (2004), Resources and coal, Small mining Encyclopedia, East Publishing House, Vol.3, Donetsk, pp. 476479 (ukr).

13. Kicky, Jerzy (2002), The role of coal: World, Europe, Poland, Mining and Metallurgical Academy, Krakow, 20 p. (pol).

14. Biletsky, V. and Sergeyev, P. and Krut, O. (2013), Fundamentals of highly loaded coal-water slurries (Наукові основи висококонцентрованих водовугільних суспензій). Mining of Mineral Deposits, CRC Press Taylor \& Francis Group, London, UK. A Balkema Book, 105-114. DOI: 10.1201/b16354-20

15. Biletsky, V. (2003), Problem processing of salt coals, Proceedings of Sciences. the islands named. Shevchenko, Vol. $X$ (Chemistry and Biochemistry), Lviv, 205-227 (ukr).

16. Wuhan Design \& Research Institute of China Coal Technology \& Engineering Group, available at: http://www.zmwhy.com.cn/ en/gczs/gdsm.asp

\section{Сапицкая Ирина,}

кандидат технических наук, дочент,

Донецүкий нацииональный университет им. В. Стуса, Украина

Чудек Мирослав,

профессор, Технологический университет Силезии, Гливице, Польша

Мальцева Ирина,

кандидат наук по государственному управлению, доиент,

Донецккий национальный университет им. В. Стуса, Украина

\section{ОРГАНИЗАЦИОННЫЕ ИЗМЕНЕНИЯ В УГОЛЬНОЙ ОТРАСЛИ ЗАРУБЕЖНЫХ СТРАН}

В статье определено, что в угольной промышленности многих зарубежных стран осуществлялось реформирование, в результате которого происходил поиск эффективных путей принятия организационных, финансовых, социально-экономических и технических решений.

\section{СХІД № 1 (147) січень-лютий 2017 р.}


Кратко рассмотрен опыт проведения организационных изменений в угольной отрасли таких стран, как: Польша, Германия, Франция, Великобритания, Бельгия, Испания, США. Выделены основные цели этого процесса. Обоснованы роль государства, этапы и методы реструктуризации угольных шахт. Охарактеризованы социально-экономические аспекты проведения изменений в различных странах.

Ключевые слова: организационные изменения; угольная промышленность; зарубежный опыт; социально-экономическое обеспечение.

Сапицька Ірина, кандидат технічних наук, доцент,

Донецький наиіональний університет ім. В. Стуса, Украӥна

Чудек Мирослав, професор, Технологічний університет Сілезії, Глівіцее, Польщча

Мальцева Ірина, кандидат наук з державного управління, доцент, Донецький національний університет ім. В. Стуса, Украӥна

\section{ОРГАНІЗАЦІЙНІ ЗМІНИ У ВУГІЛЬНІЙ ГАЛУЗІ ЗАКОРДОННИХ КРАЇН}

Стаття присвячена організаційним змінам у вугільній промисловості зарубіжних країн. Ії реформування характерно практично для всіх вугледобувних країн світу. Виділено наступні цілі організаційних змін: збільшення обсягів видобутку вугілля (США, ПАР, Австралія, Китай, Індія); підвищення конкурентоспроможності підприємств і ліквідація збиткових шахт (Польща, Чехія, Україна); перехід на альтернативні енергоносії та зменшення обсягів видобутку (Німеччина, Франція, Великобританія).

Показано, що у всіх державах процес змін базувався на розроблених кожною країною програмах і моделях. Так, наприклад, у Польщі значна увага приділялася законодавчому забезпеченню, у якому визначалися джерела фінансування, особливі права шахтарських регіонів, процедури ліквідації шахт; розглядалися проблеми зайнятості і соціального захисту шахтарів. У Німеччині процес реформування відбувався за моделлю "соціального миру та партнерства", що забезпечило чітку координацію між усіма рівнями уряду і представниками профспілок, які здійснювали соціальний захист шахтарів. Вугільна промисловість Великобританії пережила націоналізацію, а згодом і приватизацію. У країні передбачена її значна підтримка шляхом гарантованого збуту видобутого всередині країни вугілля; виплати допомоги звільненим шахтарям. При цьому поступово збільшувався розмір вихідної допомоги і знижувався віковий поріг. У Франції на початку 60-х рр. XX століття була прийнята енергетична стратегія, яка передбачала інтенсивний розвиток атомної енергетики і поступове закриття шахт. Першорядна увага приділялась не достроковому виходу на пенсію, а перепідготовці та працевлаштуванню шахтарів. Рішення уряду Бельгії знизити, а потім відмовитися від вуглевидобутку в країні, було викликано переважно посиленням громадського тиску, спрямованого на припинення субсидування галузі. Уряд розробив програму, яка передбачала не тільки закриття шахт, а й оновлення економічної активності регіону. Процес реструктуризації відбувався за "м'яким" сценарієм. Уряд Іспанії здійснює поступове скорочення активності у вугільній промисловості. Процес супроводжується масштабним субсидуванням державної компанії, можливістю раннього виходу на пенсію, забезпеченням високого рівня соціального захисту шахтарів. У США, з огляду на високу мобільність робочих, вуглевидобувні компанії не мають спеціальних програм 3 їх працевлаштування та соціального захисту. Роль уряду обмежується виплатою звичайної допомоги з безробіття. Прямої державної підтримки підприємствам немає, фінансуються лише загальногалузеві наукові програми. Непряма підтримка здійснюється через жорстке регулювання діяльності енергогенеруючих компаній.

Наведений зарубіжний досвід реформування вугільної промисловості доцільно використовувати в процесі організаційних змін базової галузі України з урахуванням сформованих соціально-економічних умов.

Ключові слова: організаційні зміни; вугільна промисловість; зарубіжний досвід; соціально-економічне забезпечення.

(C) Сапицька Ірина, Чудек Мирослав, Мальцева Ірина

Надійшла до редакції 07.02.2017

СХІД № 1 (147) січень-лютий 2017 р. 